Zeszyty Naukowe Szkoły Głównej Gospodarstwa Wiejskiego w Warszawie

Problemy Rolnictwa Światowego tom 18 (XXXIII), zeszyt 2, 2018: 291-302

DOI: $10.22630 /$ PRS.2018.18.2.56

Krystyna Świetlik $^{1}$

Instytut Ekonomiki Rolnictwa i Gospodarki Żywnościowej - Państwowy Instytut

Badawczy w Warszawie

\title{
Światowe i krajowe ceny żywności w latach 2016-2017
}

\section{Global and Domestic Food Prices During 2016-2017}

\begin{abstract}
Synopsis. Otwarcie polskiej gospodarki w wyniku transformacji systemowej i integracji europejskiej zwiększyło jej zależność od zjawisk o charakterze globalnym. W ostatniej dekadzie światowe ceny i podaż żywności doświadczały poważnych szoków, co miało istotne konsekwencje dla polskiego rynku żywnościowego. Celem artykułu jest przedstawienie zmian cen żywności w Polsce w latach 2016-2017 na tle tendencji występujących na rynkach światowych, ze szczególnym uwzględnieniem rynku unijnego, określenie siły ich wzajemnych powiązań oraz wskazanie czynników warunkujących te procesy. W wyniku przeprowadzonych analiz stwierdzono, że w Polsce w badanym okresie ceny żywności rosły szybciej niż w UE, ale wolniej niż na rynkach światowych, wykazywały mniejszą wahliwość niż na rynkach zewnętrznych oraz bardzo wysoką korelację ze zmianami cen w UE. Powiązanie z rynkiem unijnym było szczególnie widoczne w przypadku cen produktów mlecznych, zbóż, mięsa wieprzowego, roślin oleistych i cukru.
\end{abstract}

Slowa kluczowe: żywność, szoki podażowe, niestabilność cen, rynek globalny, Unia Europejska.

\begin{abstract}
The opening of the Polish market as a result of systemic transformation and European integration increased its dependence on changes in global factors. During the last decade global prices and food supplies experienced serious shocks, which had significant consequences for the Polish food market. The objective of this paper is to present changes in food prices in Poland during 2016-17 against a backdrop of global trends, with particular emphasis on the EU market, a description of the strength of their mutual relationship and an indication of the factors affecting these processes. As a result of the analyses, it was concluded that during the studied period prices in Poland increased faster that in the EU, but more slowly than global prices. They showed a smaller tendency to oscillate than in external markets and a very high correlation with changes in EU prices. The connection with the EU market was particularly apparent in the case of prices of dairy products, cereal crops, pork, vegetable oils and sugar.
\end{abstract}

Key words: food, supply shocks, unstable prices, global market, European Union

JEL Classification: F43, E31, E32, O13, Q11

\section{Wprowadzenie}

Ceny żywności z uwagi na łatwość kwantyfikacji stanowią stały przedmiot badań teoretycznych i praktycznych (stosowanych), podejmowanych zwłaszcza w krajach, w których system gospodarczy od lat opiera się na regułach gospodarki rynkowej. W Polsce ceny żywności należą do najczęściej rozpatrywanych czynników wpływających na poziom i strukturę spożycia artykułów żywnościowych oraz sprawność rynku

\footnotetext{
${ }^{1}$ dr hab., prof. IERiGŻ-PIB, Zakład Badań Rynkowych IERiGŻ-PIB, ul. Świętokrzyska 20, 00-002 Warszawa, e-mail: krystyna.swietlik@ierigz.waw.pl
} 


\section{K. Świetlik}

żywnościowego. Są one współkomponentem układu cen w gospodarce żywnościowej, podstawowym wyznacznikiem kosztów utrzymania rodzin oraz istotnym, pozamonetarnym składnikiem inflacji (Noga, 2009, s. 151-157). Z tego względu budzą żywe zainteresowanie opinii publicznej, naukowców, polityków i praktyków gospodarczych. Szczególnie duże zainteresowanie wzbudza ruch cen żywności w okresach ich silnych fluktuacji. Takim okresem były w Polsce m.in. lata 2005-2017 z uwagi na różnokierunkowe zmiany cen żywności, a zwłaszcza problematyczną szybkość, gwałtowność i wysokość ich wahań. Były one konsekwencją uwarunkowań wewnętrznych związanych z produkcją i podażą surowców rolniczych, postępującego procesu integracji europejskiej i globalizacji, lecz przede wszystkim znaczących turbulencji cenowych na światowym rynku artykułów rolnospożywczych (Świetlik, 2016a). Światowa niestabilność cen żywności skutkowała wydatnym ich wzrostem w latach 2007-2008, tj. w okresie światowego kryzysu żywnościowego oraz gwałtownym, rekordowym wzrostem w 2011 r., a następnie głębokim ich spadkiem w kolejnych pięciu latach. Interesująco przedstawiały się zmiany światowych cen żywności w latach 2016-2017. W połowie 2016 r. odnotowano zahamowanie utrzymującego się od 2012 r. spadkowego ich trendu i powrót do tendencji wzrostowej. Po przyspieszeniu w I półroczu 2017 r., dynamika wzrostu cen ponownie spowolniła aż do wartości ujemnej w końcu roku.

Akcesja Polski do Unii Europejskiej i związane z tym otwarcie polskiej gospodarki zwiększyło jej zależność od zjawisk o charakterze globalnym i wrażliwość na różnego rodzaju kryzysy. O krajowych cenach artykułów rolno-spożywczych zaczęły decydować głównie ceny światowe oraz rynki krajów sąsiadujących i rynki globalne, nie zaś zmiany krajowych relacji podaży i popytu. Z przeglądu notowań cen wynika, że w latach 2005-2015 na polskim rynku żywnościowym wystapiły zjawiska podobne do obserwowanych na rynkach światowych i europejskich. Zmiany cen krajowych podążały za zmianami cen światowych, dotyczyły tych samych produktów spożywczych, różniły się natomiast skala zmian (Świetlik, 2016b). W kontekście zjawisk zachodzących na globalnym rynku artykułów rolno-spożywczych w latach 2016-2017, zrozumiała wydaje się próba znalezienia odpowiedzi na pytanie, czy odnotowane $\mathrm{w}$ tym okresie zmiany światowych cen żywności znalazły odzwierciedlenie w zmianach cen na unijnym i polskim rynku, czy krótkookresowe zmiany cen na rynkach globalnych są równie transparentne w ujęciu przestrzennym i czasowym, jak zmiany długookresowe? Tak sformułowanemu głównemu celowi rozważań podporządkowano następujące cele cząstkowe: zobrazowanie kierunków i skali zmian światowych, unijnych i krajowych cen żywności, kwantyfikacja stopnia ich zmienności i siły powiązania, przedstawienie zmian cen poszczególnych grup artykułów żywnościowych oraz identyfikacja czynników je determinujących w ostatnich dwóch latach.

\section{Materiał badawczy i metodyka badań}

Podstawą analiz przeprowadzonych dla celów niniejszego artykułu były szeregi statystyczne charakteryzujące badane kategorie cenowe zaczerpnięte $\mathrm{z}$ baz danych Organizacji Narodów Zjednoczonych do spraw Wyżywienia i Rolnictwa (FAO), Europejskiego Urzędu Statystycznego (Eurostat) oraz Głównego Urzędu Statystycznego (GUS). Zakres czasowy analiz obejmował głównie lata 2016-2017, lecz w niektórych przypadkach odwołano się do lat wcześniejszych, co umożliwiło wyciągnięcie bardziej prawidłowych wniosków. W celu dokonania pomiaru dynamiki cen żywności ogółem oraz 
poszczególnych jej grup posłużono się zagregowanymi średniorocznymi indeksami cen o stałej i zmiennej podstawie. Przy obliczaniu skumulowanych indeksów dla okresu 20162017 za rok odniesienia przyjęto rok 2015. Do charakterystyki krótkookresowej zmienności cen wykorzystano miesięczne indeksy cen o stałej i zmiennej podstawie. Do analizy stopnia zmienności cen żywności zastosowano współczynniki zmienności, które obliczono jako relację odchylenia standardowego do średniej geometrycznej indeksów cen (rocznych i miesięcznych) traktując wielkości wskaźnikowe jako liczby rzeczywiste (Wawrzynek, 2007, s. 37). Siłę związku pomiędzy światowymi, unijnymi i krajowymi cenami żywności określono na podstawie współczynnika korelacji liniowej Pearsona. Źródłem informacji o uwarunkowaniach transformacji cenowych struktur były także wyniki własnych, wieloaspektowych analiz statystyki rynkowej oraz specjalistyczne krajowe i zagraniczne publikacje naukowe i popularno-naukowe. Do oceny zebranego materiału badawczego zastosowano metodę statystyki opisowej i porównawczej.

Rozważając zmiany światowych cen żywności trzeba pamiętać o specyficznej metodzie ich kalkulacji, odmiennej od metodologii przyjętej przez Eurostat i GUS. W statystykach GUS i Eurostatu ceny żywności są identyfikowane z cenami produktów finalnych. W badaniach FAO do konstrukcji indeksu cen żywności przyjmuje się zarówno ceny surowców rolniczych, jak i produktów przetworzonych. Indeks cen żywności FAO jest miarą miesięcznych zmian międzynarodowych cen określonego koszyka towarów spożywczych. Stanowi on średnią pięciu subindeksów towarowych: mięsa, produktów mlecznych, zbóż, olejów roślinnych i cukru, ważoną średnimi udziałami w eksporcie każdej z grup w latach 2002-2004. Każdy z subindeksów jest średnia ważona względnych cen towarów w danej grupie, z przyjęciem jako ceny bazowej średnich za lata 2002-2004².

Analizując zmienność cen żywności w Unii Europejskiej posłużono się tzw. zharmonizowanymi wskaźnikami cen konsumpcyjnych (HICP) obliczanymi przez kraje członkowskie według ujednoliconej metodologii. Podstawę do opracowania HICP stanowi system wag oparty na strukturze spożycia indywidualnego w sektorze gospodarstw domowych ze statystyki rachunków narodowych (Rocznik..., 2017a, s. 742-743). Obliczane według tej metodologii indeksy cen dla Polski różnią się od wskaźników opracowywanych przez GUS przy zastosowaniu systemu wag opartego na strukturze wydatków gospodarstw domowych (bez spożycia naturalnego) szacowanej na podstawie wyników badań budżetów gospodarstw domowych (Rocznik..., 2017b, s. 445).

\section{Zmiany światowych cen żywności}

Kierunki zmian cen żywności na rynkach globalnych budzą duże zainteresowanie zwłaszcza w sferze praktyki gospodarczej, gdyż decydują o kształtowaniu się opłacalności międzynarodowych transakcji handlowych oraz prowadzonej działalności gospodarczej i to zarówno na szczeblu mikro, jak i makroekonomicznym. W okresach silnych zmian i przekształceń, światowe ceny żywności stają się przedmiotem zainteresowania nie tylko

\footnotetext{
${ }^{2}$ Indeks cen mięsa jest kalkulowany na podstawie cen 27 produktów mięsnych reprezentujących cztery rodzaje mięsa, tj. drób, wołowinę, wieprzowinę i baraninę. Indeks cen zbóż jest obliczany na podstawie notowań cen pszenicy, kukurydzy i ryżu prowadzonych przez Międzynarodową Izbę Zbożową. Indeks cen przetworów mlecznych obliczany jest na podstawie cen masła, odtłuszczonego i pełnego mleka w proszku oraz serów. Do konstrukcji indeksu cen olejów roślinnych przyjmuje się średnią ważoną względnych cen dziesięciu produktów $\mathrm{z}$ tej grupy.
} 


\section{K. Świetlik}

przedstawicieli praktyki i nauki, ale również szerszych kręgów społeczeństwa. Negatywne konsekwencje ich wzrostu są odczuwalne głównie w regionach o relatywnie niskim dochodzie per capita oraz przez gospodarki krajów, które są importerami netto żywności. Zjawiska te wystapily m.in. w minionej dekadzie w następstwie notowanego od $2007 \mathrm{r}$. znaczącego wzrostu światowych cen artykułów rolno-spożywczych i dużych wahań jego tempa w poszczególnych latach (rys. 1).

Wysoki wzrost cen żywności doprowadził wiosną 2008 r. do wybuchu światowego kryzysu żywnościowego (Daszkowska, 2007; Rising..., 2008; Trostle, 2008; The State..., 2009), który zakończył trzy dekady relatywnie niskich cen produktów rolno-spożywczych na rynkach międzynarodowych. Według FAO w 2008 r., w porównaniu z 2006 r., światowe ceny żywności zwiększyły się o $58,3 \%^{3}$, co było efektem zmian globalnego popytu na żywność oraz niekorzystnych warunków podażowych na światowych rynkach rolnych (Mold, 2011). Tę niekorzystną sytuację pogłębił m.in. wzrost światowych cen paliw i surowców energetycznych. Silne zwyżkowe trendy cen surowców rolno-spożywczych i energetycznych na rynkach globalnych powróciły w 2011 r. W 2011 r. światowe ceny żywności osiagnęły rekordowy poziom - o 14,2\% wyższy w porównaniu z 2008 r. (Headey, 2016; Sousa, 2017; Świetlik, 2011).

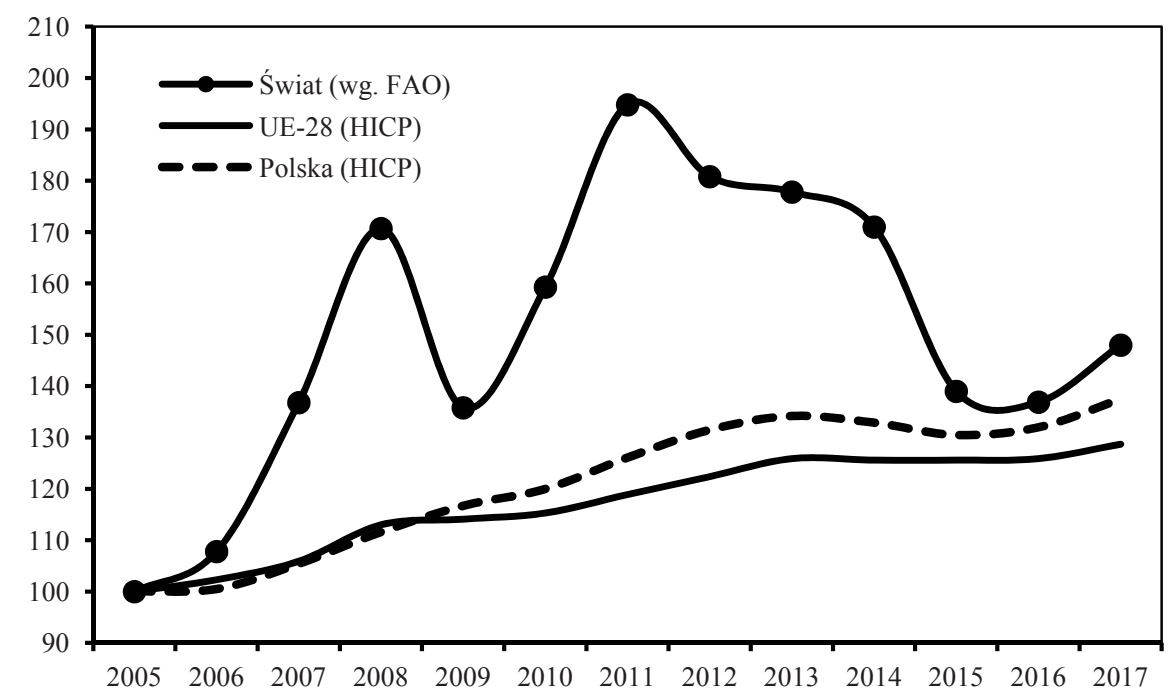

Rys. 1. Wskaźniki cen żywności (2005 r.=100)

Fig. 1. Food price indices $(2005=100)$

Źródło: obliczenia i opracowanie własne na podstawie FAOSTAT, Eurostat i GUS.

W 2012 r. rozpoczął się proces tanienia żywności na międzynarodowych rynkach, który trwał do 2016 r. W 2016 r., w porównaniu z 2011 r., światowe ceny żywności obniżyły się o $30 \%{ }^{4}$. Głównymi czynnikami sprawczymi tego zjawiska były: wzrost podaży żywności, spowolnienie dynamiki wzrostu światowego popytu i spadek cen

\footnotetext{
${ }^{3}$ Ceny mięsa wzrosły o 33\%, produktów mlecznych o 72\%, zbóż o 95,2\%, a tłuszczów roślinnych o 201,5\%.

${ }^{4}$ Ceny zbóż zmalały o $39 \%$, olejów roślinnych o $35,6 \%$, cukru o $30,6 \%$, produktów mlecznych o $33 \%$, a mięsa o $14,8 \%$.
} 
surowców energetycznych, w tym zwłaszcza ropy naftowej, a także węgla kamiennego i gazu, tj. surowców silnie skorelowanych z dynamiką cen żywności (From Energy..., 2016; Lempert, 2017; OECD and FAO..., 2017; Trends..., 2016). Na relatywnie niskich poziomach utrzymywały się także światowe ceny surowców rolnych.

Spadek średnich rocznych cen żywności na rynkach międzynarodowych w 2016 r. był relatywnie niewielki i wyniósł $1,5 \%$. Najbardziej, bo o 9,5\% obniżyły się światowe ceny zbóż. Ceny mięsa zmalały o $7,1 \%$, a produktów mlecznych o $4,1 \%$. Wzrosły natomiast ceny olejów roślinnych (o 11,4\%) i cukru (o 34,2\%). Zmiany te były wypadkową dwóch przeciwstawnych tendencji występujących $\mathrm{w}$ pierwszej i drugiej połowie roku. W I półroczu 2016 r. światowe ceny żywności były niższe niż w I półroczu 2015 r., w połowie roku zbliżyły się do notowanych rok wcześniej, a od sierpnia do grudnia istotnie przewyższały poziomy sprzed roku. W grudniu $2016 \mathrm{r}$. były one o $11 \%$ wyższe niż przed rokiem (rys. 2).

W grudniu 2016 r., w relacji do grudnia 2015 r., wzrosły ceny wszystkich monitorowanych przez FAO produktów, z wyjątkiem zbóż. Najbardziej, bo o 29,3\% podrożały oleje roślinne głównie w wyniku wzrostu cen oleju palmowego i sojowego. Wzrost ten był skutkiem niskich światowych zapasów oleju palmowego oraz zwiększonego zużycia oleju sojowego przez sektor biodiesla w USA, Brazylii i Argentynie. O wzroście cen produktów mlecznych (o 28,8\%) zadecydował wzrost cen masła, serów i pełnego mleka w proszku, przy stabilizacji cen odtłuszczonego mleka w proszku. Światowe ceny cukru osiagnęly w grudniu 2016 r. poziom o 26,4\% wyższy, niż rok wcześniej, lecz w przeciwieństwie do cen innych produktów, w pierwszej połowie roku rosły szybciej niż w drugiej, głównie z powodu obaw o spadek produkcji tego surowca w Brazylii, która jest największym światowym producentem i eksporterem cukru oraz w Indii - drugiego pod względem wielkości producenta i Tajlandii. Do spowolnienia dynamiki cen cukru w II półroczu 2016 r. przyczyniło się osłabienie brazylijskiego reala wobec dolara USA, a także informacje o możliwym wzroście produkcji cukru w Brazylii w sezonie 2016/2017. W grudniu 2016 r. ceny mięsa na światowych rynkach były o 4,7\% wyższe niż rok wcześniej. W ostatnich miesiącach roku wzrosły głównie ceny wołowiny na skutek spadku podaży eksportowej tego mięsa z Australii. W drugiej połowie 2016 r. nasiliła się natomiast spadkowa tendencja cen zbóż, w tym głównie pszenicy, na skutek oczekiwanych wzrostów produkcji w Australii, Kanadzie i Rosji. W grudniu 2016 r. światowe ceny zbóż były o 6,2\% niższe niż w grudniu $2015 \mathrm{r}$.

Zapoczątkowana w sierpniu 2016 r. wzrostowa tendencja światowych cen żywności utrzymała się do lipca 2017 r. Od sierpnia 2017 r. żywność na globalnych rynkach zaczęła tanieć (rys. 2). W ostatnich miesiącach 2017 r. istotnie zmalały ceny cukru, olejów roślinnych i produktów mlecznych. W efekcie w grudniu $2017 \mathrm{r}$. światowe ceny żywności ukształtowały się na poziomie o $0,7 \%$ niższym niż w analogicznym okresie przed rokiem. Jednakże z uwagi na utrzymujący się względnie wysoki ich poziom w pierwszej połowie roku, w całym $2017 \mathrm{r}$. były one o $8,1 \%$ wyższe niż w roku poprzednim. Najbardziej, bo o $31,5 \%$ zwiększyły się średnie roczne ceny produktów mlecznych. Wzrost cen mięsa wyniósł $8,9 \%$, zbóż $3,2 \%$, a olejów roślinnych 3,1\%. Spadły jedynie ceny cukru (o 11,2\%). Spośród produktów mlecznych istotnie podrożały: masło, sery i pełnothuste mleko w proszku. Ceny masła wzrosły z powodu zwiększającego się spożycia w USA, Unii Europejskiej i popytu importowego ze strony Chin, w warunkach obniżającej się produkcji i podaży oraz rosnących cen surowca mlecznego. Do wzrostu cen zbóż przyczyniło się podrożenie pszenicy w związku z obniżeniem prognoz jej podaży i niepokojącym stanem zapasów. O wzroście cen 


\section{K. Świetlik}

mięsa zadecydował wzrost cen wieprzowiny stymulowany rosnącym popytem w gospodarkach wschodzących w wyniku poprawy koniunktury gospodarczej tych krajów. Spadek cen cukru związany był ze stosunkowo słabym popytem importowym połączonym ze spodziewaną w sezonie 2017/2018 pierwszą od dwóch lat nadwyżką podaży na światowym rynku cukru, wynikająca ze zniesienia kwot cukrowych w UE oraz zwiększenia produkcji cukru trzcinowego przez głównych producentów, tj. Brazylię, Indie, Chiny i Tajlandię, przy zmniejszonym wykorzystaniu cukru do produkcji bioetanolu.

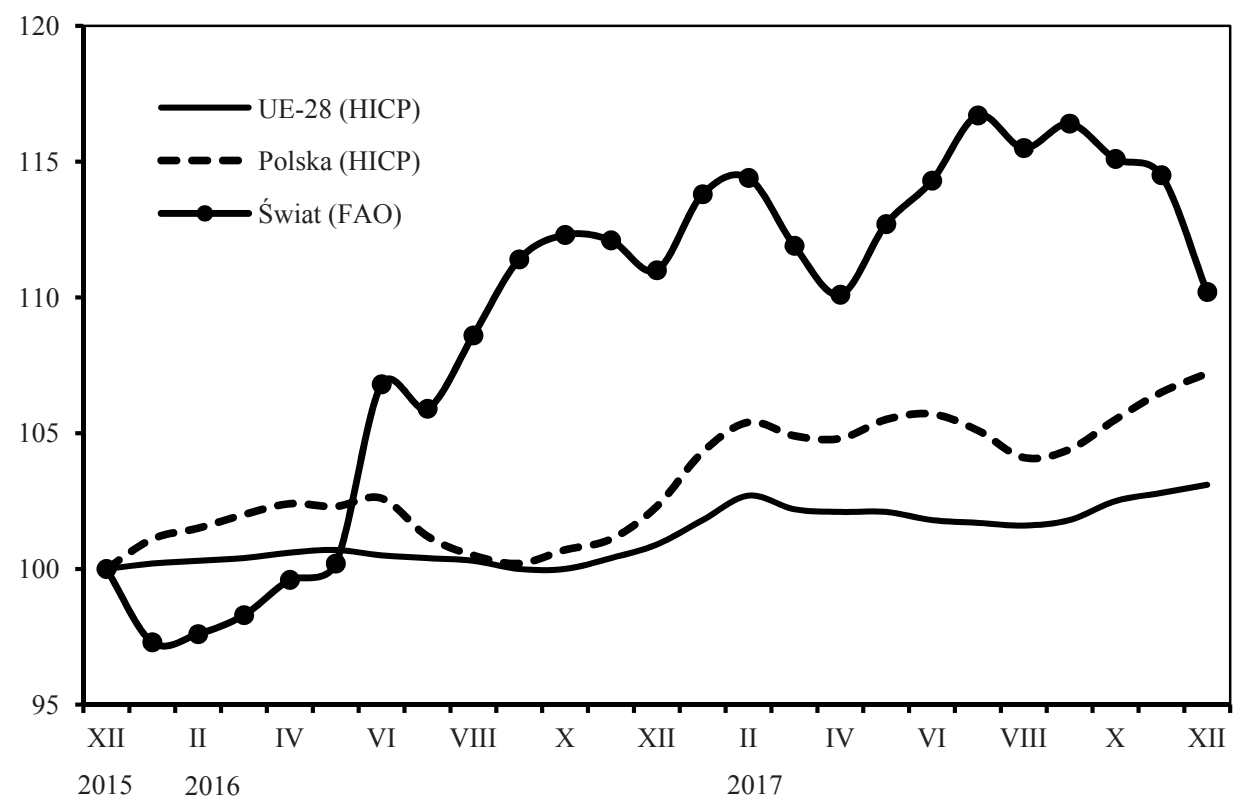

Rys. 2. Miesięczne wskaźniki cen żywności (XII 2015 r. = 100)

Fig. 2 Monthly indices of food prices (December $2015=100$ )

Źródło: opracowanie i obliczenia własne na podstawie FAOSTAT i Eurostat.

Z przeprowadzonej analizy wynika, że w latach 2016-2017 miesięczne zmiany światowych cen żywności były różnokierunkowe, ale wzrosty przeważały nad spadkami. W efekcie w 2017 r. przeciętny poziom cen żywności był o 6,5\% wyższy niż w 2015 r., a w grudniu 2017 r. o 10,2\% wyższy niż w analogicznym miesiącu przed rokiem.

W latach 2005-2017 zmienność rocznych cen żywności monitorowanych przez FAO, mierzona współczynnikiem zmienności, wyniosła 14,8\%. Ustalając wartość tego współczynnika dla lat 2016-2017 wykorzystano indeksy miesięczne, a w celu eliminacji sezonowości posłużono się wskaźnikami zmian w stosunku do analogicznego miesiąca roku poprzedniego. Wyniki badań pokazały, że w latach 2016-2017 światowe ceny żywności cechowała większa stabilność niż w latach wcześniejszych. Średnia wartość współczynnika zmienności miesięcznych indeksów cen dla tego okresu ukształtowała się na poziomie 9,3\%. Poszukując przyczyn zmienności cen żywności na rynkach światowych w latach 2016-2017 stwierdzono, że były nimi głównie szoki podażowe. 


\section{Zmiany cen żywności w Unii Europejskiej}

$\mathrm{Z}$ analizy materiału empirycznego zgromadzonego dla potrzeb niniejszego artykułu wynika, że w latach 2005-2017 zmiany cen żywności w Unii Europejskiej były zbieżne z tendencjami na świecie, przy dużym zróżnicowaniu ich dynamiki w poszczególnych okresach (rys. 1) ${ }^{5}$. Niekiedy przebiegały one w przeciwnych kierunkach, lecz generalnie na rynku unijnym odchylenia cen od linii trendu były mniejsze niż na rynkach międzynarodowych. Skokowy wzrost światowych cen żywności w latach 2007-2011 oraz głęboki ich spadek w latach 2012-2016 skutkował przyspieszeniem, a następnie spowolnieniem dynamiki wzrostu cen unijnych. W UE, w przeciwieństwie do rynku światowego, w żadnym roku nie odnotowano deflacji cen żywności. W 2016 r., gdy na świecie ceny żywności piąty rok z rzędu ulegały redukcji, w UE minimalnie wzrosły (o $0,3 \%$ ). Znaczący wzrost światowych cen żywności w 2017 r. (o 8,1\% w stosunku do roku poprzedniego) znalazł odzwierciedlenie we wzroście cen żywności w UE, lecz dużo mniejszym niż na międzynarodowych rynkach $(2,2 \%)$. Spadek światowych cen żywności w ostatnich miesiącach 2017 r. nie wywołał analogicznych zmian na unijnym rynku żywnościowym (rys. 2). W 2017 r., w porównaniu z 2015 r., światowe ceny żywności zwiększyły się o $6,5 \%$, a unijne o $2,5 \%$ (tab. 1).

Tabela 1. Wskaźniki cen żywności w latach 2016-2017

Table 1. Food price indices in 2016-2017

\begin{tabular}{|c|c|c|c|c|c|c|}
\hline \multirow{3}{*}{ Wyszczególnienie } & 2016 & \multicolumn{2}{|c|}{2017} & XII 2016 & \multicolumn{2}{|c|}{ XII 2017} \\
\hline & \multicolumn{2}{|c|}{$\begin{array}{l}\text { rok poprzedni } \\
\quad=100\end{array}$} & $\begin{array}{l}2015 \\
=100\end{array}$ & \multicolumn{2}{|c|}{$\begin{array}{l}\text { XII poprzedniego } \\
\text { roku }=100\end{array}$} & $\begin{array}{l}\text { XII } 2015 \\
=100\end{array}$ \\
\hline & \multicolumn{6}{|c|}{ Żywność (bez napojów bezalkoholowych) } \\
\hline UE-28 (HICP) & 100,3 & 102,2 & 102,5 & 101,1 & 102,6 & 103,7 \\
\hline Strefa euro (HICP) & 100,7 & 101,8 & 102,5 & 101,2 & 102,0 & 103,2 \\
\hline Polska (HICP) & 101,1 & 104,2 & 105,3 & 102,6 & 105,3 & 108,0 \\
\hline Świat (FAO) & 98,5 & 108,1 & 106,5 & 111,0 & 99,3 & 110,2 \\
\hline
\end{tabular}

Źródło: FAOSTAT, Eurostat i obliczenia własne.

Z przeprowadzonych badań wynika, że zarówno $\mathrm{w}$ długich, jak i krótkich okresach, inflacja żywnościowa w Unii Europejskiej była dodatnio skorelowana ze światowymi cenami żywności. Współczynnik korelacji pomiędzy zmianami średnich rocznych światowych i unijnych cen żywności w latach 2005-2017 wyniósł 0,64. Współczynnik korelacji obliczony dla lat 2016-2017 pomiędzy miesięcznymi wskaźnikami cen w stosunku do analogicznych miesięcy z roku poprzedniego był mniejszy, lecz statystycznie istotny, gdyż wyniósł 0,50. W latach 2016-2017 powiązania rynku unijnego ze światowym rynkiem żywności były szczególnie widoczne w przypadku kształtowania się cen produktów mlecznych, zbóż, mięsa, olejów roślinnych i cukru.

Zarówno w latach 2016-2017, jak i we wcześniejszych okresach sytuacja cenowa na detalicznym rynku żywności Unii Europejskiej była dużo bardziej stabilna niż na

\footnotetext{
${ }^{5}$ Mowa tu o zmianach cen żywności szacowanych dla UE-28.
} 
światowym rynku żywnościowym. W latach 2005-2017 współczynnik zmienności średnich rocznych cen żywności w UE wyniósł $1,9 \%$, podczas gdy współczynnik zmienności światowych cen żywności kształtował się na poziomie 14,8\%. W latach 2016-2017 współczynniki zmienności miesięcznych indeksów cen żywności w UE i na rynku światowym wyniosły odpowiednio $1,04 \%$ i $9,3 \%$.

Dociekając przyczyn zaobserwowanych zjawisk zauważono, że wolniejszy wzrost cen żywności w Unii Europejskiej niż na rynkach światowych był m.in. efektem wysokiej produkcji i podaży żywności, przekraczającej poziom zapotrzebowania wewnętrznego. W latach 2000-2015 UE osiagnęła produkcję pozwalająca na pokrycie zapotrzebowania wewnętrznego $\mathrm{w}$ zakresie wszystkich podstawowych artykułów rolno-spożywczych (Świetlik, 2017a, s. 23). Istotnym czynnikiem wpływającym na osłabienie powiązań między światowymi i unijnymi cenami żywności oraz zmniejszenie zmienności cen unijnych w badanym okresie był stosunkowo duży stopień integracji unijnego rynku oraz silna regulacja produkcji rolnej w UE w ramach Wspólnej Polityki Rolnej. Znaczna czesść krajów unijnych posiada wspólną walutę i wspólną politykę pieniężną kreowaną przez Europejski Bank Centralny, co stwarza szansę na podobny przebieg cen. Skale krótkookresowych zmian światowych i unijnych cen żywności różniły się natomiast z powodu odmiennych uwarunkowań popytowo-podażowych. W latach 2016-2017 wzrost produktu krajowego brutto (PKB) w świecie wyniósł 6,9\% (w cenach stałych), w tym w Unii Europejskiej 4,3\%, podczas gdy w krajach rozwijających się i wschodzących $9,1 \%$. Wydatny wzrost zamożności w krajach biedniejszych stymulował popyt na żywność i zmianę jego struktury w kierunku droższego koszyka, co sprzyjało wzrostowi cen żywności (World Economic..., 2017, s. 15, 242-243). W niektórych przypadkach krótkoterminowe zmiany światowych cen artykułów rolno-spożywczych nie zostały w pełni przeniesione na ceny żywności w UE ze względu na zmiany kursów walut, w tym głównie relacji euro do dolara. W badaniach FAO ceny żywności wyrażone są $\mathrm{w}$ dolarach, co powoduje, że osłabienie waluty amerykańskiej oznacza wzrost światowych cen żywności, jak to miało miejsce w $2017 \mathrm{r}$.

\section{Zmiany cen żywności w Polsce}

Z analizy opracowywanych przez GUS szeregów czasowych cen wynika, że w Polsce w latach 2005-2017 trend nominalnych cen żywności miał charakter wzrostowy i był spójny $\mathrm{z}$ trendami światowymi oraz unijnymi. Istotne jego nasilenie odnotowano w latach 2007-2008 i w 2011 r. W latach 2012-2013, pod wpływem znaczacego spadku cen artykułów rolno-spożywczych na rynkach globalnych, wzrost cen żywności w Polsce wyraźnie spowolnił, a w latach 2014-2015 był ujemny (tab. 2). Deflacja cen żywności była zjawiskiem nienotowanym od 2003 r. Po dwóch latach spadków, z początkiem 2016 r. krajowe ceny żywności zaczęły rosnąć i w grudniu były o 2,7\% wyższe niż rok wcześniej (rys. 2). Ich średni roczny poziom wzrósł o $1,0 \% \mathrm{w}$ porównaniu z rokiem poprzednim. Zmiany te przebiegały odmiennie niż na rynkach światowych (spadek średnich rocznych cen żywności) i w UE (stabilizacja).

Analizując ich uwarunkowania wykazano, że miały one charakter lokalnej specyfiki, związanej z produkcją i podażą artykułów rolno-spożywczych. W I półroczu $2016 \mathrm{r}$. 
w kierunku wzrostu cen żywności oddziaływała mniejsza krajowa podaż podstawowych ziemiopłodów oraz owoców i warzyw ze zbiorów w 2015 r. w następstwie suszy ${ }^{6}$. W II półroczu wzrost cen żywności był w dużej mierze efektem wzrostu cen produktów mięsnych i nabiałowych wynikającego ze zmniejszeniem pogłowia zwierząt hodowlanych z powodu niskiej opłacalności produkcji mięsa i mleka ${ }^{7}$. Wzrostowi krajowych cen żywności w 2016 r. dodatkowo sprzyjały czynniki globalne, związane z sytuacją na światowych rynkach surowców energetycznych i rolnych ${ }^{8}$ oraz słabszy niż w poprzednim roku kurs złotego, jak również ożywienie popytu krajowego wspierane przez wzrost zatrudnienia i płac, wypłaty świadczeń wychowawczych z programu „Rodzina 500+” i bardzo dobre nastroje konsumentów (Świetlik, 2017b, s. 26-29).

Tabela 2. Wskaźniki cen żywności i napojów bezalkoholowych w Polsce

Table 2. Price indices of food and non-alcoholic beverages in Poland

\begin{tabular}{|c|c|c|c|c|}
\hline \multirow{2}{*}{ Wyszczególnienie } & 2014 & 2015 & 2016 & 2017 \\
\hline & \multicolumn{4}{|c|}{ rok poprzedni $=100$} \\
\hline Żywność i napoje bezalkoholowe & 99,1 & 98,3 & 100,8 & 104,2 \\
\hline Żywność & 99,1 & 98,2 & 101,0 & 104,6 \\
\hline Pieczywo i produkty zbożowe & 100,1 & 99,6 & 100,4 & 102,1 \\
\hline Warzywa, ziemniaki i przetwory & 96,4 & 99,3 & 102,8 & 102,9 \\
\hline Owoce i przetwory & 97,2 & 101,7 & 105,5 & 108,0 \\
\hline Mięso, podroby i przetwory & 98,9 & 97,0 & 100,0 & 104,8 \\
\hline Ryby i owoce morza & 100,0 & 99,7 & 103,6 & 103,4 \\
\hline Oleje i tłuszcze & 99,7 & 93,6 & 99,2 & 116,0 \\
\hline Masło & 102,5 & 89,9 & 99,2 & 131,0 \\
\hline Mleko i przetwory & 103,8 & 96,9 & 98,0 & 104,9 \\
\hline Jaja & 93,7 & 98,0 & 97,8 & 112,9 \\
\hline Cukier, dżem, miód, czekolada i wyroby cukiernicze & 93,5 & 99,1 & 105,0 & 102,5 \\
\hline Cukier & 71,2 & 91,0 & 126,9 & 105,5 \\
\hline
\end{tabular}

Źródło: (Ceny..., 2016, s. 41-42; Biuletyn..., 2018, s. 141-143), niepublikowane dane GUS.

W 2017 r. dynamika cen żywności uległa przyspieszeniu. Wzrost cen żywności w stosunku do roku poprzedniego wyniósł 4,6\% i był najwyższy od 2011 r. Podobnie jak w 2016 r. wynikał on głównie z oddziaływania czynników wewnętrznych związanych z ograniczeniem krajowej podaży niektórych produktów rolnych, m.in. owoców, mleka i żywca wieprzowego. Dodatkowo wspierały go: wzrost pozasurowcowych kosztów przetwórstwa i obrotu związany ze wzrostem jednostkowych kosztów pracy oraz cen

${ }^{6}$ W 2015 r., w porównaniu z rokiem poprzednim, zbiory zbóż zmalały o 12,3\%, rzepaku o 17,6\%, ziemniaków o $17,9 \%$, buraków cukrowych o 30,6\%, warzyw gruntowych o 18,2\%, a owoców o 2,1\% (Wyniki..., 2016, s. 21).

${ }^{7}$ W grudniu 2016 r. cena żywca wieprzowego była o ok. 31\% wyższa niż w grudniu 2015 r. W I półroczu 2016 r. ceny skupu mleka spadły o ok. 10\%, a w II półroczu wzrosły o 5,7\% (w skali roku). W grudniu 2016 r. w skupie za mleko płacono o ok. 20\% więcej niż w grudniu 2015 r. (Rolnictwo..., 2017, s. 29, 70).

${ }^{8} \mathrm{~W}$ drugiej połowie 2016 r. znacząco wzrosły światowe ceny ropy naftowej i węgla kamiennego oraz cukru, olejów roślinnych i mleka. 
energii i paliw, zwiększenie się krajowego popytu na żywność w warunkach wydatnej poprawy sytuacji dochodowej gospodarstw domowych i wzmożenie eksportu. Wzrost cen niektórych produktów (m.in. masła i jaj) był stymulowany przez ich zwyżkę na rynkach globalnych, a w szczególności na rynku unijnym.

W 2017 r., w porównaniu z rokiem poprzednim, wzrosły ceny większości monitorowanych przez GUS grup produktów spożywczych. Najbardziej, bo o $16 \%$ zwiększyły się ceny tłuszczów jadalnych, głównie za sprawą wzrostu cen masła o 31\%. Jaja podrożały o $12,9 \%$, a owoce o $8 \%$, w tym jabłka o $21,6 \%$. Ceny artykułów mleczarskich wzrosły o 4,9\%, w tym jogurtów o 7,3\%, śmietany o 7\%, a serów dojrzewających o $6,8 \%$. Wzrost cen mięsa i jego przetworów wyniósł $4,8 \%$ i był efektem wydatnego podrożenia wieprzowiny (o 8,6\%). Droższe niż rok wcześniej były również: cukier (o 5,5\%), ryby i owoce morza (o 3,4\%) oraz warzywa (o 2,9\%).

Wzrost cen żywności w grudniu 2017 r., w relacji do grudnia 2016 r., wyniósł 5,8\% i był wyższy od średniorocznego z uwagi na przyspieszenie jego tempa w drugiej połowie roku spowodowane m.in. wydatnym podrożeniem jaj, masła, owoców krajowych, w tym zwłaszcza jabłek i mięsa drobiowego (Świetlik, 2018, s. 71-76). W ostatnich miesiącach 2017 r. istotnie natomiast potaniał cukier, co miało związek ze zniesieniem kwot cukrowych w UE od 1 października 2017 r. oraz wzrostem produkcji cukru w Polsce, w UE i u największych światowych producentów umożliwiającym odbudowę światowych zapasów tego produktu.

Warto podkreślić, że zarówno w latach 2016-2017, jak i w całym poakcesyjnym okresie Polska należała do krajów o najwyższej dynamice cen żywności w Unii Europejskiej. W latach 2016-2017 wzrost cen żywności miał miejsce w 25 krajach unijnych i był największy na Łotwie (o 7,5\%), w Estonii (o 5,9\%), w Polsce (o 5,3\%), na Litwie (o 4,9\%) i w Czechach (o 4,6\%). Wyższy wzrost cen żywności w krajach UE-12 niż w krajach „starej Unii” był efektem mniejszej integracji rynków oraz postępującego procesu konwergencji.

Analizując zmiany cen żywności w Polsce na tle ich zmian w UE oraz na rynkach światowych stwierdzono, że w 2017, w stosunku do 2015 r., krajowe ceny żywności zwiększyły się o 5,2\% (HICP), przy wzroście cen światowych o 6,5\% i unijnych o 2,5\% (HICP). W latach 2016-2017 współczynnik zmienności miesięcznych indeksów cen żywności (obrazujących zmiany cen $\mathrm{W}$ stosunku do analogicznych miesięcy roku poprzedniego) w przypadku cen światowych wyniósł 9,27\%, unijnych 1,04\%, a polskich $1,71 \%$. Współczynnik korelacji pomiędzy miesięcznymi indeksami światowych i unijnych cen żywności kształtował się na poziomie 0,50, pomiędzy indeksami cen światowych i polskich 0,34, zaś pomiędzy miesięcznymi indeksami cen żywności w Polsce i w UE 0,94.

W 2017 r., w porównaniu z 2005 r., światowe ceny żywności zwiększyły się o 48\%, unijne o 28,6\%, a krajowe o 37,3\%. Współczynnik zmienności średnich rocznych indeksów światowych cen żywności dla tego okresu wyniósł 14,8\%, indeksów cen w UE 1,9\%, a w Polsce 2,4\%. Współczynnik korelacji pomiędzy indeksami średnich rocznych światowych i unijnych cen żywności osiagnął wartość 0,65 , pomiędzy indeksami cen światowych i krajowych wyniósł 0,53, a pomiędzy indeksami rocznych cen żywności w UE i w Polsce - 0,73.

W długim okresie zmiany cen żywności w Polsce były zgodne pod względem kierunku z cenami na międzynarodowych rynkach, natomiast w krótkich okresach dały się zauważyć pomiędzy nimi pewne rozbieżności wynikające z odmiennych uwarunkowań podażowo-popytowych. O przesunięciu w czasie reakcji cen krajowych na zmiany cen światowych świadczą m.in. następujące fakty: na przełomie lat 2014-2015, tj. w czasie, gdy w Polsce notowano największe nasilenie deflacji, a ceny żywności spadały o 3-4\%, indeks 
FAO obniżał się nawet o ponad 20\%. Późniejszemu wzrostowi krajowych cen artykułów żywnościowych w latach 2016-2017 towarzyszyła zwyżka indeksu cen światowych od 10 do $17 \%$. Po raz ostatni 10\%. wzrost światowych cen żywności notowano w lipcu 2017 r, po czym jego skala systematycznie zmniejszała się, w odróżnieniu od wskaźnika krajowych cen żywności, który uległ obniżeniu dopiero w końcu roku.

\section{Podsumowanie}

Przeprowadzone analizy pokazały, że:

- w Polsce w latach 2016-2017, podobnie jak w całym poakcesyjnym okresie (20052017) ceny żywności rosły szybciej niż w UE, lecz wolniej niż na międzynarodowych rynkach;

- $\quad$ sytuacja cenowa na polskim rynku żywnościowym była bardziej stabilna niż na rynkach światowych, lecz mniej stabilna niż na rynku unijnym;

- zmiany cen artykułów rolno-spożywczych na rynkach światowych wywoływały podobne zmiany cen na krajowym rynku żywnościowym, lecz wskaźniki krajowych cen żywności podążały za indeksem światowym $\mathrm{z}$ pewnym opóźnieniem i dlatego w krótkich okresach różniły się pod względem wielkości;

- dynamiki zmian cen poszczególnych grup żywności w Polsce były bardziej zbliżone do zmian w UE niż do dynamiki cen światowych;

- wyniki analiz i rozważań teoretycznych prowadzą do wniosku, że w długim okresie decydujący wpływ na kształtowanie się cen żywności mają czynniki strukturalne, popytowe, natomiast krótkookresowa zmienność cen żywności jest konsekwencją głównie wahań popytu i podaży w czasie trwania cyklu produkcyjnego, determinowanych m.in. przez zjawiska pogodowe, zmiany kursów walutowych, stany zapasów oraz koniunkturalne wahania cen paliw i surowców energetycznych;

- przeprowadzone analizy empiryczne i rozważania teoretyczne dostarczaja przesłanek do przewidywania rozwoju cen żywności w bliższej i dalszej perspektywie czasowej. Z uwagi na silną globalną integrację rynków rolnożywnościowych, można oczekiwać, że obniżające się w pierwszych miesiącach 2018 r. światowe ceny artykułów mięsnych, olejów roślinnych i cukru będą oddziaływać w kierunku ich spadku w UE oraz w Polsce.

\section{Literatura}

Biuletyn Statystyczny (Statistical bulletin). (2018). GUS, Warszawa, 12/2017.

Ceny w gospodarce narodowej w 2016 r. (Prices in the national economy in 2016). (2017). GUS, Warszawa.

Daszkowska, E. (2009). Przyczyny i odczuwalne skutki kryzysu żywnościowego pierwszej dekady XXI wieku. Działania stabilizujące sytuację podejmowane przez Unię Europejską i Bank Światowy (The reasons and perceptible effects of the food crisis in the first decade of the 21 th century. Activities taken by the European Union and the World Bank aimed at stabilizing the situation). Journal of Agribusiness and Rural Development, 4(10), 17-23.

From energy prices to food prices: Moving in tandem? (2016). Commodity Markets Outlook. A World Bank Quaterly Report, World Bank Group, Washington, D.C., July 2016, 1-80. Pobrane 15 stycznia 2018 z: http://www.worldbank.org/commodities. 
Headey, D. (2016). Food Prices and Poverty. Policy Research Working Paper, no 7898, 1-47. World Bank, Washington, DC. Pobrane 15 stycznia 2018 z: https://openknowlege.worldbank.org/handle/10986/25701.

Lempert P. (2017). Food Deflation Is Changing The Face Of Retail. Forbes. Free Issues, Februar 1. Pobrane 15 stycznia $2018 \mathrm{z}$ : http://www.forbes.com/sites/.

Mold, A. (2011). Shifting Wealth and the Consequences of Rising Food Prices on Social Cohesion: A Diagnosis and Policy Responses. OECD, Paris, 1-33. Pobrane 15 stycznia 2018 z: http://www.oecd.org/dev/pgd/ 46921010.pdf.

Noga, M. (2009). Makroekonomia (Macroeconomics). Wydawnictwo Uniwersytetu Ekonomicznego we Wrocławiu, Wrocław.

OECD and FAO see slower growth in demand keeping world food prices low. (2017). OECD, Paris, 1-3. Pobrane 15 stycznia 2018 z: http://www.oecd.org/newsroom/.

Rising Food Prices. Couses and Consequences. (2008). OECD, Paris, 1-9. Pobrane 15 stycznia 2018 z: http://www.oecd.org/trade/agricultural-trade/40847088.pdf.

Rocznik Statystyczny Rzeczypospolitej Polskiej 2017 (Statistical Yearbook of the Republic of Poland 2017). (2017a). GUS, Warszawa.

Rocznik Statystyczny Rzeczypospolitej Polskiej 2017 (Statistical Yearbook of the Republic of Poland 2017). (2017b). GUS, Warszawa.

Rolnictwo w 2016 r. (Agriculture in 2016) (2017). GUS, Warszawa.

Sousa, P. (2017). What did we learn from the bouth of high and volatile food commodity prices (2007-2013)? FAO Commodity and Trade Policy Research Working Paper. FAO, Rome, nr 54, 1-34. Pobrane 15 stycznia $2018 \mathrm{z}$ : http://www.fao.org.

Świetlik, K. (2011). Ceny żywności w 2011 r. i przewidywane ich zmiany w 2012 r. (Food prices in 2011 and changes forecast for 2012). Przemyst Spożywczy, 4, 2-7.

Świetlik, K. (2016a). Ceny detaliczne żywności w Polsce w latach 2003-2015 (Retail prices of food in Poland in 2003-2015). Handel Wewnętrzny, 6(365), 181-196.

Świetlik, K. (2016b). Makroekonomiczne ujęcie zmian cen żywności w Polsce w latach 2001-2015 (Macroeconomic view of changes in food prices in Poland during 2001-2015). W: M. Hamulczuk (red.) Ceny żywności w Polsce i ich determinanty (Food prices in Poland and their determinants). IERiGŻ-PIB, Warszawa. Monografie Programu Wieloletniego, 29, 50-58.

Świetlik, K. (2018). Rynek żywnościowy. Rynek Rolny. Biuletyn Miesięczny (Food market. Agricultural market. Monthly bulletin). IERiGŻ-PIB, Warszawa 2(324), 71-76.

Świetlik, K. (red.). (2017a), Ewolucja światowego i krajowego popytu na żywność w kontekście zmian demograficznych i bezpieczeństwa żywnościowego (The evolution of global and domestic demand for food in the context of demographic changes and food security). IERiGŻ-PIB, Warszawa. Monografie Programu Wieloletniego, 65, 1-223.

Świetlik, K. (red.). (2017b). Popyt na żywność. Stan i perspektywy. Analizy rynkowe (Demand for food. Conditions and perspectives. Market analyses). IERiGŻ-PIB, KOWR, MRiRW, Warszawa, 18, 1-109.

The State of Agricultural Commodity Markets. High food prices and the food crisis - experiences and lessons learned. (2009). FAO, Rome, 1-68. Pobrane 15 stycznia 2018 z: http://www.fao.org.

Trends in foreign direct investment in food, beverages and tobacco. (2016). FAO Commodity and Trade Policy Research Paper, nr 51, 1-46. FAO, Rome. Pobrane 15 stycznia 2018 z: http://www.fao.org/3/a-i5595e.pdf.

Trostle, R. (2008). Global Agricultural Supply and Demand: Factors Conributing to the Recent Increase in Food Commodity Prices, A Report from the Economic Research Servive. USDA, Washington D.C. WRS-0801, 1-30. Pobrane 15 stycznia 2018 z: http://www.ers.usda.gov.

Wawrzynek, J. (2007). Metody opisu i wnioskowania statystycznego (Methods of reporting and statistical conclusion). Wydawnictwo Akademii Ekonomicznej im. Oskara Langego we Wrocławiu, Wrocław.

World Economic Outlook. Seeking Sustainable Growth: Short-Term Recovery, Long-Term Challenges. (2017). IMF, Washington, D,C., October 2017, 15, 242-243. Pobrane 15 stycznia 2018 z: http://www.imf.org/ external/pubs/ft/weo/2017/02/weodata/.

Wyniki produkcji roślinnej w 2015 r. (Crop production in 2015). (2016). GUS, Warszawa.

Do cytowania / For citation:

Świetlik K. (2018). Światowe i krajowe ceny żywności w latach 2016-2017. Problemy Rolnictwa Światowego, 18(2), 291-302; DOI: 10.22630/PRS.2018.18.2.56

Świetlik K. (2018). Global and Domestic Food Prices During 2016-2017 (in Polish). Problems of World Agriculture, 18(2), 291-302; DOI: 10.22630/PRS.2018.18.2.56 